\title{
Effects of Intracellular Zinc Chelator In Vivo on Taurine Transport, Taurine Concentrations and Taurine Transporter in Rat Retina Cells
}

\author{
Asarí Márquez $^{1 *}$, Mary Urbina ${ }^{1}$, Manuelita Quintal ${ }^{2}$, Francisco Obregón ${ }^{1}$ and Lucimey Lima ${ }^{1}$ \\ ${ }^{1}$ Neurochemistry Laboratory, Center for Biophysics and Biochemistry, Venezuelan Institute for Scientific Research, Caracas, Venezuela \\ ${ }^{2}$ Laboratory of Analytical Chemistry, Chemistry Center, Venezuelan Institute for Scientific Research, Caracas, Venezuela
}

\begin{abstract}
Taurine and zinc, highly concentrated in the retina, have neurotrophic effects in the central nervous system. Zinc modulates $\mathrm{Na}^{+} / \mathrm{Cl}$ - dependent transporters, such as those of dopamine and taurine (TAUT) in vitro, although there is no evidence of in vivo effects of zinc. The objectives of the present study were to evaluate the consequences of zinc deficiency on taurine levels and transport, and mRNA levels of TAUT in rat retina. Various concentrations of the intracellular zinc chelator, $N, N, N, N$-tetrakis-(2-pyridylmethyl) ethylenediamine (TPEN), dissolved in dimethylsulfoxide, were administered intraocular for dose selection: 1, 2.5 and $5 \mathrm{nM}(12.5,31.25$ and $62.5 \mathrm{nM}$ final concentrations). Dilution in the eye is approximately 25 times. It is taking into account the volume of the eye, $12.5 \mu \mathrm{l}$ ). Retinas were dissected 3, 5 and 10 days later. Zinc was determined by spectrophotometry. TPEN administration, 5 $\mathrm{nM}$, decreased zinc in $67 \%$ at 5 days. Taurine levels, determined by high performance liquid chromatography with fluorescence detection, were $65.96 \pm 4.73 \mathrm{nmoles} / \mathrm{mg}$ protein in tissue, $44.34 \pm 5.55$ in isolated cells, and in 6.63 \pm 1.12 in cell membranes. Capacity of taurine transport, using $\left[{ }^{3} \mathrm{H}\right]$ taurine, was decreased in $38 \%$ and affinity was increased in $50 \%$ after TPEN. mRNA levels of TAUT, by RT-PCR, were diminished in $50 \%$ by the chelator. Optimal concentrations of zinc are necessary for the equilibrium of taurine system in the retina, which involves concentrations of taurine, taurine transport and TAUT mRNA levels.
\end{abstract}

Keywords: Retina; Taurine; Taurine transport; Taurine transporter mRNA; Zinc

Abbreviations: ICP: Inductively Coupled Plasma Emission Spectrophotometry; io: Intraocular; NMG: N-methyl-glucamine; RPE: Retinal Pigment Epithelium; TAUT: Taurine Transporter; TPEN: $N, N, N, N$-tetrakis-(2-pyridylmethyl) Ethylenediamine

\section{Introduction}

Taurine possesses neuroprotective and neurotrophic properties in the central nervous system (CNS) during development and regeneration, and its levels are high in the eye, particularly in the retina, ranging from 50 to $80 \mathrm{mM}$ [1]. The system of taurine in the retina has been studied, such as synthesis, transport, storage [2-9] and cell localization [10-14]. In addition, zinc has been recognized as an essential element, crucial for development and function of CNS, abundant in plants and animals, second after iron [15]. Zinc content in the retina is also high, reaching concentrations up to $100 \mu \mathrm{g} / \mathrm{g}$ [16]. Zinc deficiency in humans has been linked to an abnormal adaptation to darkness, cataracts and blindness, as well as macular degeneration, due to decrease of antioxidants in the retina $[15,17]$. The role of zinc in the eye is associated with its coexistence with other molecules such as the amino acid taurine [16].

As pointed above, taurine and zinc possess similar functions in the CNS, related to protection and regeneration. Despite quoted experimental approaches, there is no evidence about the effects of zinc on retinal taurine system of mammals, in regard to concentration, transport activity and relative levels of mRNA of transporter. Zinc regulates several $\mathrm{Na}^{+} / \mathrm{Cl}^{-}$dependent neurotransmitter transporters, such as that of dopamine [18], norepinephrine [19], serotonin [20], and taurine (TAUT) $[8-9,12,21]$.

We have previously shown that intermediate concentrations of zinc obtained by the intracellular chelator, N,N,N,N-tetrakis-(2pyridylmethyl) ethylenediamine (TPEN) ex vivo significantly decreased $\left[{ }^{3} \mathrm{H}\right]$ taurine transport [21]. In addition, the reduction of zinc by TPEN in the retina, significantly decreased TAUT in all layers, as detected by immunohistochemistry, except in photoreceptors, indicating that the presence of zinc is necessary for maintenance of the transporter in the retina [22].

The study of possible effects of zinc on taurine system in the retina is relatively novel and of great interest for better understanding the interactions of taurine and zinc in this structure. Since both molecules have physiopathological relations, this work examined the effects caused by chelating zinc by injection of TPEN into the eye on taurine levels, taurine transport and TAUT mRNA in rat retina.

\section{Materials and Methods}

\section{Animals}

Male Sprague-Dawley rats (150-200 g) from the animal housing at Instituto Venezolano de Investigaciones Científicas had an adaptation period of at least 48 hours in the experimental room of the Laboratory, food and water provided ad libitum. The animals were decapitated between 8:00 and 10:00 am, and the eyes were extracted from orbit. Handling of animals was conducted following the standards of animal bioethics [23] and was approved by the Bioethics Committee for Animal Research of the Institute.

*Corresponding author: Asarí Márquez, Neurochemistry Laboratory, Center for Biophysics and Biochemistry, Venezuelan Institute for Scientific Research Caracas, Venezuela, Tel: +58-212-504-1213, Fax: +58-212-504-1295; E-mail: asarimarquez@gmail.com

Received March 14, 2016; Accepted April 02, 2016; Published April 09, 2016

Citation: Márquez A, Urbina M, Quintal M, Obregón F, Lima L (2016) Effects of Intracellular Zinc Chelator In Vivo on Taurine Transport, Taurine Concentrations and Taurine Transporter in Rat Retina Cells. J Membra Sci Technol 6: 149 doi:10.4172/2155-9589.1000149

Copyright: (c) 2016 Márquez A, et al. This is an open-access article distributed under the terms of the Creative Commons Attribution License, which permits unrestricted use, distribution, and reproduction in any medium, provided the original author and source are credited. 
Citation: Márquez A, Urbina M, Quintal M, Obregón F, Lima L (2016) Effects of Intracellular Zinc Chelator In Vivo on Taurine Transport, Taurine Concentrations and Taurine Transporter in Rat Retina Cells. J Membra Sci Technol 6: 149. doi:10.4172/2155-9589.1000149

Page 2 of 7

\section{Treatment with the intracellular zinc chelator $N, N, N, N$ - tetrakis-(2-pyridylmethyl) ethylenediamine in vivo}

Various concentrations of intracellular zinc chelator TPEN, 1, 2.5 and $5 \mathrm{nM}$, were administered for different periods of time 3, 5 and 10 days, for selecting the dose to be used according to zinc levels reduction [9]. Three experimental groups of rats were included:

1) Intraocular administration (io) of $1,2.5$ or $5 \mathrm{nM}$ of TPEN, final concentrations $12.5,31.25$ and $62.5 \mathrm{nM}$ (dilution in the eye is approximately 25 times. It is taking into account the volume of the eye, $12.5 \mu \mathrm{l}$ ). $2 \mu \mathrm{l}$ of saline and dimethyl sulfoxide (DMSO, $0.001 \%$ ).

2) Administration (io) of $2 \mu$ l of DMSO $0.001 \%$ final concentration (vehicle, control group).

3) Needle puncture (sham intervention).

\section{Isolation of rat retinal cells}

Retina was dissected and cells were separated with $0.25 \%$ trypsin in Locke buffer $(500 \mu \mathrm{l}$ ), composed (in $\mathrm{mM}$ ) of $154 \mathrm{NaCl}, 2.7 \mathrm{KCl}, 2.1$ $\mathrm{K}_{2} \mathrm{HPO}_{4}, 0.95 \mathrm{KH}_{2} \mathrm{PO}_{4}, 2.7$ sucrose and $2.5 \mathrm{HEPES}$, at $37^{\circ} \mathrm{C}$ for $10 \mathrm{~min}$, followed by mechanical further separation with Pasteur pipette. The cells were washed with phosphate saline buffer $\mathrm{Na}^{+}-\mathrm{K}^{+}$(PBS) $0.1 \mathrm{M}$ $\mathrm{pH} 7.4$, centrifuged for $10 \mathrm{~min}$ at 2,000 rpm (300 g), and counted in Neubauer chamber. Integrity of membrane was determined by $50 \%$ Trypan blue exclusion (>96\%) [21].

\section{Determination of total zinc}

The tissue was homogenized in $320 \mu$ of deionized distilled water, $20 \mu \mathrm{l}$ were collected for protein determination by bicinchoninic acid (BCA) assay [24], and the remainder was used for determination of total zinc. Tissue samples were dried, suspended in $1 \mathrm{ml}$ of concentrated $\mathrm{HNO}_{3}$, heated for $6 \mathrm{~h}$ at $60^{\circ} \mathrm{C}$ and made up to $10 \mathrm{ml}$ with deionized water. Inductively coupled plasma emission spectrometry (ICP-AES) was performed in a Perkin-Elmer Model Optima 3000 equipped with a U-5000AT ultrasonic nebulizer, a standard demountable-type quartz plasma torch and alumina injection ( $1.5 \mathrm{~mm}$ internal diameter). A ten-roller peristaltic pump was used to supply the gas with the sample solution. The atomic line for zinc was $213.856 \mathrm{~nm}[9,25,26]$. After verified reduction of zinc levels, $5 \mathrm{nM}$ of TPEN, 5 days after io injection was chosen for all the experiments.

\section{Determination of taurine}

Taurine was determined in rat retina: tissue, isolated cells and cell membranes, and after TPEN injection in isolated cells. HPLC with fluorescent detection was employed by a modified method [26]. The system consisted of a Waters 2690 Separation System and a Shimadzu RF-551 fluorescent detector. Separation was done with a Supelco LC18 column $4.6 \times 100 \mathrm{~mm}, 5 \mu \mathrm{m}$. The samples was resuspended and homogenized in $50 \mu \mathrm{l}$ of $20 \%$ sulfosalycilic acid and $300 \mu \mathrm{l}$ of $0.4 \mathrm{M}$ potassium borate buffer $\mathrm{pH} 10.4$ and the aliquots were subjected to protein analysis by BCA assay [24]. Centrifugation of samples was carried out at $38,000 \mathrm{~g}$ for $20 \mathrm{~min}$ at $4^{\circ} \mathrm{C}$. Derivatization was performed by addition of $200 \mu \mathrm{l}$ of the following mix: $25 \mathrm{mg}$ ortho-phthaldehyde, $500 \mu \mathrm{l}$ methanol, $25 \mu \mathrm{l} \beta$-mercaptoethanol $(1 \mathrm{~g} / \mathrm{ml})$, and $4.5 \mathrm{ml} 0.4 \mathrm{M}$ potassium borate buffer of $\mathrm{pH} 10.4$. Aliquots of the derivatized preparation were injected into the chromatographic system. Taurine was quantified by the method of the external standard and expressed in $\mathrm{nmol} / \mathrm{mg}$ of protein using the program Millenium (Waters, MA, USA) [25].

\section{Saturation of taurine transport and intracellular zinc chelator $\mathrm{N}, \mathrm{N}, \mathrm{N}, \mathrm{N}$-tetrakis-(2-pyridylmethyl) ethylenediamine in vivo on transport}

According to Márquez et al. [21], hipotaurine and beta-alanine were specific inhibitors, and number of cells, temperature and time of pre- and incubation were fixed. For saturation assays, the cell preparation $(250,000$ cells per tube) was incubated in the presence of various concentrations of $\left[{ }^{3} \mathrm{H}\right]$ taurine from 15 to $165 \mathrm{nM}$ (488 and 629 $\mathrm{GBq})$. For each concentration, duplicate tubes were prepared in a final volume of $500 \mu \mathrm{l}$. The preparation was pre-incubated at $37^{\circ} \mathrm{C}$ for $5 \mathrm{~min}$ in Locke solution. Incubation, $25 \mathrm{~s}$, was started by the addition of the substrate.

Subsequently, after the incubation, the process was stopped by rapid filtration through fiberglass filters (Watman GF/C), followed by two washed with $5 \mathrm{ml}$ of cold Locke solution as previously described [21]. High and low-affinity components of transport were evaluated, and transport capacity $\left(\mathrm{V}_{\text {max }}\right)$ and affinity constant $\left(\mathrm{K}_{\mathrm{t}}\right)$ were calculated for control and treated rats.

Levels of mRNA of taurine transporter after io injection of intracellular zinc chelator $N, N, N, N$-tetrakis-(2pyridylmethyl) ethylenediamine in vivo

TAUT mRNA levels in cells isolated from rat retina were determined by reverse transcription polymerase chain reaction (RT-PCR) [27-32] with primers designed such that a 707-base pair fragment of rB16a could be amplified from cDNA [33]. The sequences of the sense and antisense primer specific for rat TAUT, were derived from amino acids 40-47 (5'ACGCTTCGACTTCCTCATGTCCTGT $\left.3^{\prime}\right)$ and 268-275 (5' TTAGAGTTGTCCACAGTCGGAGATG $3^{\prime}$ ), respectively [33]. To verify the integrity of the cDNA synthesized and semi-quantification was performed with specific sense ( $\beta$-act-S: $5^{\prime}$-TCATGAAGTGTGACGTTGACATCCGT-3') and antisense primers ( $\beta$-act-AS: 5 '-CTTAGAAGCATTTGCGGTGCACGAATG-3') for the mRNA of the gene $\beta$-actin (Promega). RNA $(1 \mu \mathrm{g})$ from rat retinal cells was converted to single-stranded cDNA by random priming using Reverse Transcriptase System (Promega). PCR reactions were carried out with GoTaq Hot start Polymerase (Promega). The RT-PCR of all experimental groups was done in a final volume of $50 \mu \mathrm{l}: 15 \mu \mathrm{l}$ of the reaction of cDNA synthesis as substrate; 1X PCR buffer, $25 \mathrm{mM}$ $\mathrm{MgCl}_{2}, 0.2 \mathrm{mM}$ nucleotide mixture, $1 \mu \mathrm{M}$ primers for TAUT and 0.05 $\mu \mathrm{M}$ of $\beta$-actin primers. The reaction was incubated under the following conditions: for 30 cycles of $94^{\circ} \mathrm{C}$ for $2 \mathrm{~min}, 68^{\circ} \mathrm{C}$ for $2 \mathrm{~min}$ and $72^{\circ} \mathrm{C}$ for $3 \mathrm{~min}$ [33]. For visualization of the fragments electrophoresis was performed in $2 \%$ agarose gel prepared in $1 \mathrm{X}$ Tris/borate/EDTA buffer (TBE) composed (in mM) (89 Trizma base, 89 boric acid and 2 EDTA, $\mathrm{pH} 8$ ) and with $0.0001 \%$ ethidium bromide. $15 \mu \mathrm{l}$ Of the RT-PCR product were taken, mixed with $2 \mu \mathrm{l}$ of $6 \mathrm{X}$ loading buffer (Promega) and plated on the gel. The running conditions were $120 \mathrm{~V}(9 \mathrm{~V} / \mathrm{cm})$ for 1 hour. The images were taken with a GelDoc 2000TM (Biorad). Densitometry analysis was performed using Quantity One v.4.2.0 (Biorad) commercial software. Relative mRNA levels were expressed as densitometry intensities of the corresponding bands for the TAUT divided by those of $\beta$-actin [34].

\section{Statistical Analysis}

Each value represents mean \pm standard error of the mean (SEM). The statistical significance of the specific data was determined by ANOVA with the program INSTAT followed by Tukey test [35]. Saturation curves were analyzed using the program GraphPad Prisma 
2. $\mathrm{V}_{\max }$ and $\mathrm{K}_{\mathrm{t}}$ of taurine transport were calculated either by LineweaverBurk plots or curvilinear analysis. Values of $\mathrm{p}<0.05$ were considered for statistically significance.

\section{Results}

\section{Zinc levels after io injection of intracellular zinc chelator}

There was no significant difference between the groups receiving the vehicle, DMSO or the needle puncture, thus control group was that with injection of DMSO was observed that the concentration of zinc in the control group was $93.75 \pm 10.66 \mu \mathrm{g} / \mathrm{mg}$ of protein. Zinc levels were significantly decreased to $37.66 \pm 3.4 \mu \mathrm{g} / \mathrm{mg}$ of protein at 5 days after the io administration of TPEN in a concentration of $5 \mathrm{nM}$ with respect to DMSO $\left(\mathrm{F}_{3,20}=9.39\right) \mathrm{P}<0.05$ (Figure $\left.1 \mathrm{~A}\right)$. At 3 and 10 days, TPEN did not produce a significant decrease in zinc levels in the retinas of the eyes treated with different concentrations of the chelators compared to DMSO $\left(\mathrm{F}_{3,20}=1.79 \mathrm{P}>0.05\right.$ and $\mathrm{F}_{3,20}=1.401 \mathrm{P}>0.05$, respectively $)$ (Figures $1 \mathrm{~B}$ and $1 \mathrm{C}$ ). The treatment with TPEN did not modify $\mathrm{Ca}^{2+}$, $\mathrm{Mg}^{2+}, \mathrm{Fe}^{2+}$, and $\mathrm{Na}^{+}$levels in the retina.

\section{Taurine levels after injection of intracellular zinc chelator}

Taurine levels were $65.96 \pm 4.73 \mathrm{nmoles} / \mathrm{mg}$ of protein in retinal tissue, $44.34 \pm 5.55$ in isolated cells, and $6.63 \pm 1.12$ in cell membranes. The concentration of taurine in isolated cells from DMSO was 48.07 $\pm 8.84 \mathrm{nmoles} / \mathrm{mg}$ of protein and was significantly reduced in $66.62 \%$ $(16.05 \pm 2.37 \mathrm{nmoles} / \mathrm{mg}$ of protein) at 5 days after the io administration of $5 \mathrm{nM}$ TPEN (Figure 2).

\section{Taurine transport after injection of intracellular zinc chelator}

The analysis of saturation experiments of $\left[{ }^{3} \mathrm{H}\right]$ taurine transport was best fitted to a two-site model (Figure 3A). In the presence of increasing concentration of $\left[{ }^{3} \mathrm{H}\right]$ taurine covering the high affinity range, there was best fit to a one-site model (Figure $3 \mathrm{~B}$ ). The value of $\mathrm{V}_{\max }$ was 9.77 $\pm 1.46 \mathrm{fmol} / 10^{6}$ cells and for $K_{t}=0.08 \pm 0.04 \mu \mathrm{M}$ (Figure 4). 5 Days after the io administration of $5 \mathrm{nM}$ TPEN, taurine transport decreased respect to control group (Figure 5). There was a significant reduction of $38.24 \%$ in the capacity and significant increase of $50 \%$ in the affinity for taurine (Table 1).

\section{Levels of mRNA of taurine transporter after injection of} intracellular zinc chelator

The levels of mRNA TAUT in the DMSO group were $3.83 \pm 0.53$ equivalents. There was a significant decrease in relative levels of mRNA TAUT after treatment with TPEN: $2.06 \pm 0.39$ (Figures 6 and 7).

\section{Discussion}

\section{Zinc levels and effect of intracellular zinc chelator}

Intracellular and extracellular levels of zinc are critical for the proper functioning of the nervous system [36]. Total content of zinc in plasma is about $100 \mathrm{mg} / 100 \mathrm{ml}$, which variations depending

\begin{tabular}{|c|c|c|}
\hline \multicolumn{3}{|c|}{ Transport of $\left[{ }^{3} \mathbf{H}\right]$ taurine } \\
\hline Days & $\mathbf{V}_{\max }\left(\mathbf{f m o l} / \mathbf{1 0}^{\mathbf{6}}\right.$ cells) & $\mathbf{K}_{\mathbf{t}}(\boldsymbol{\mu M})$ \\
\hline Control 5 d & $5.02 \pm 0.63$ & $0.06 \pm 0.01$ \\
\hline 5 nM TPEN 5 d & $3.10 \pm 0.20^{*}$ & $0.03 \pm 0.01 *$ \\
\hline
\end{tabular}

$\mathrm{V}_{\max }$ and $\mathrm{K}_{t}$ were calculated by Lineweaver-Burk linearization. Each value is the mean \pm SEM, $n=4$. * $P<0.05$ with respect to Control

Table 1: Effect of io administration $5 \mathrm{nM}$ of $N, N, N, N$-tetrakis-(2-pyridylmethyl) ethylenediamine (TPEN) on $\left[{ }^{3} \mathrm{H}\right]$ taurine transport in isolated cells from rat retinal after 5 days of injection
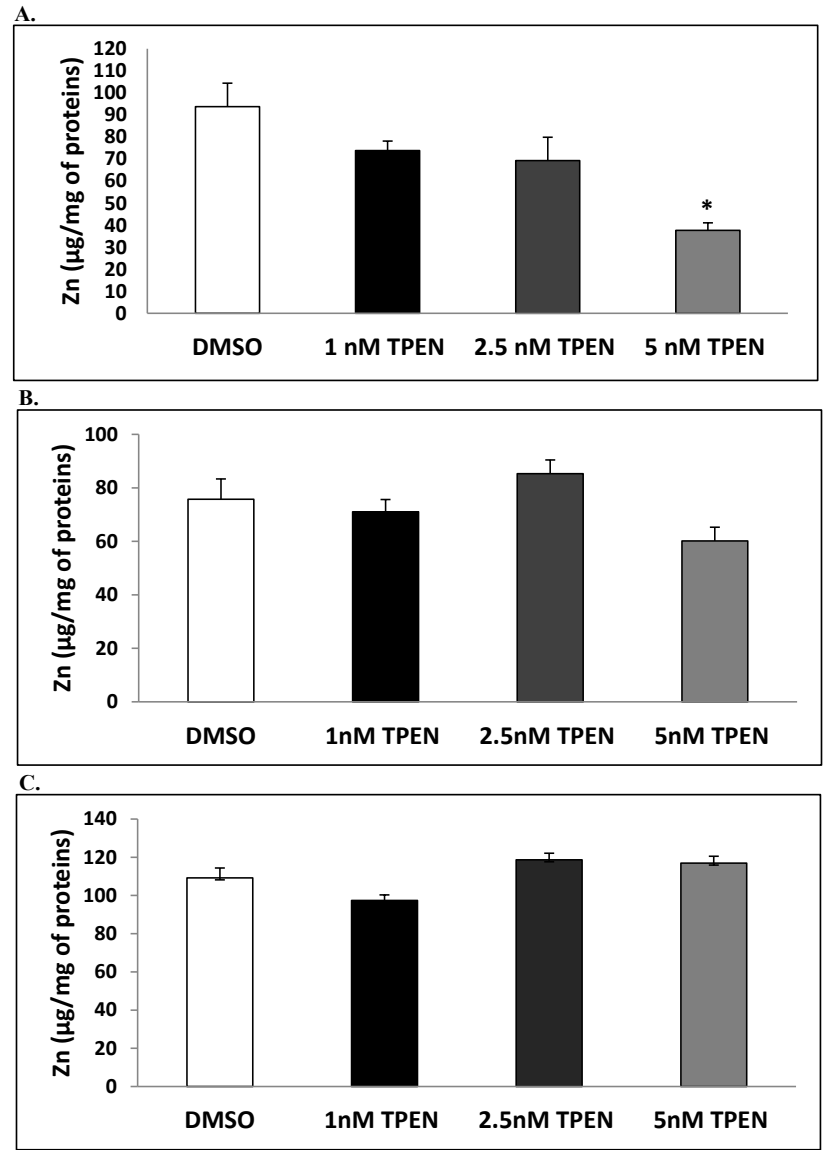

Figure 1: Effect of various concentrations $(1,2.5$ or $5 \mathrm{nM})$ of $N, N, N, N-$ tetrakis-(2-pyridylmethyl) ethylenediamine (TPEN) in vivo on zinc levels in rat retina after intraocular injection: A) 3, B) 5 and C) 10 days. Each value is the mean \pm SEM, $n=6$. * $p<0.05$ with respect to dimethyl sulfoxide, DMSO (vehicle, control group). At 5 days after the io administration of TPEN in a concentration of $5 \mathrm{nM}$ with respect to DMSO $\left(F_{320}=9.39\right) \mathrm{P}<0.05$ At 3 and 10 days, TPEN compared to DMSO $\left(\mathrm{F}_{3,20}=1.79 \mathrm{P}>0.05\right.$ and $\mathrm{F}_{3,20}=1.401 \mathrm{P}$ $>0.05$, respectively).

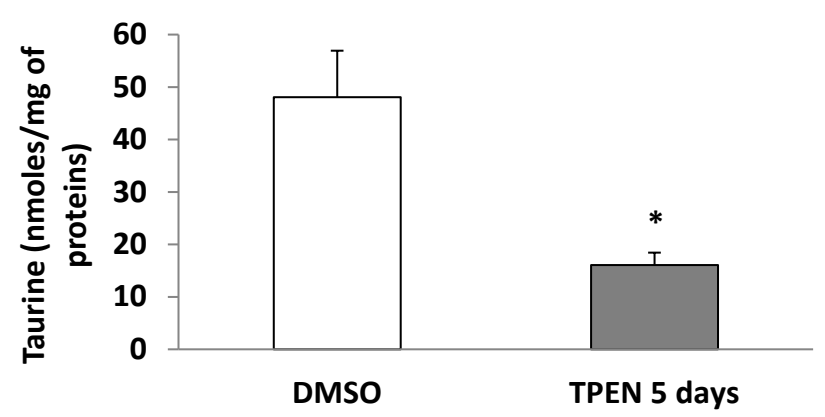

Figure 2: Effect of $N, N, N, N$-tetrakis-(2-pyridylmethyl) ethylenediamine (TPEN) in vivo on taurine levels in the rat retina. Taurine levels were determined by HPLC to $5 \mathrm{nM}$ of the chelator and 5 days after injection io. Each value is the mean \pm SEM, $n=4$. * $p 0.05$ with respect to DMSO.

on age, gender, pregnancy and time of day [15,37]. The intracellular concentration of total zinc is around $100 \mu \mathrm{M}$, and in cytoplasm, between 3 and $100 \mathrm{nM}$, facing extracellular zinc below $500 \mathrm{nM}$ [38]. Zinc, 1 to $50 \mu \mathrm{M}$, increases neuronal excitability and greater than 100 $\mu \mathrm{M}$ is inhibitory [38]. During intense activity in the hippocampus, zinc gets to $300 \mu \mathrm{M}$ in cytoplasm [38] and up to $20 \mathrm{mM}$ in vesicles [37]. 

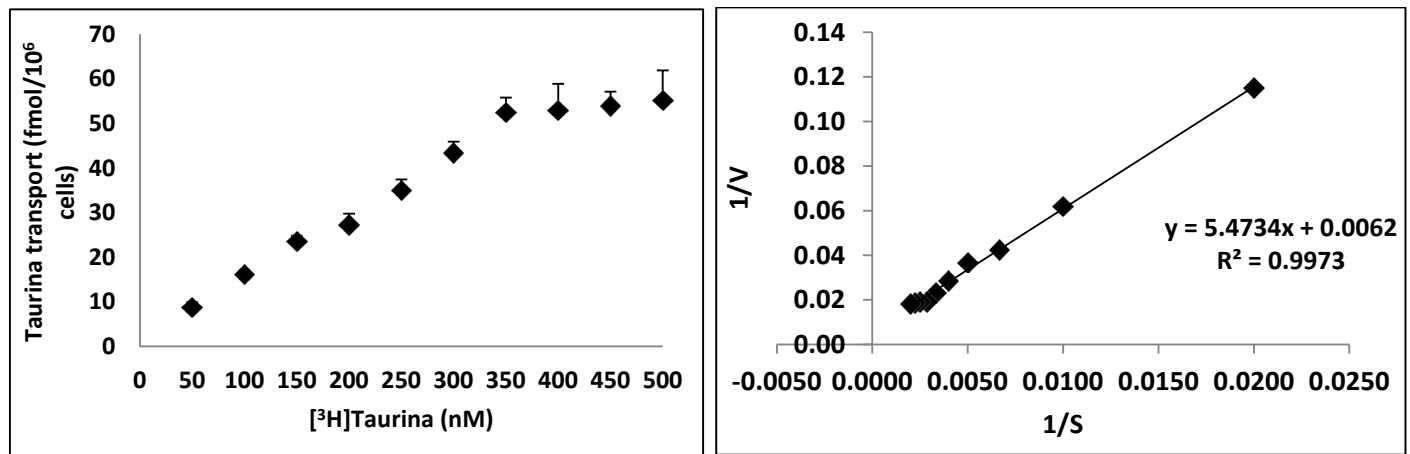

Figure 3: Curve of the saturation of $\left[{ }^{3} \mathrm{H}\right]$ taurine transport into rat retinal cells determined by presence of concentrations of [ $\left.{ }^{3} \mathrm{H}\right]$ taurine from 50 to $500 \mathrm{nM}$. Data were best fitted to: A) a rectangular hyperbole $R^{2}=0.97, \mathrm{n}=5$ and B) Lineweaver-Burk analysis of the same results of Figure $\mathrm{A} R^{2}=0.997, \mathrm{n}=4$. Each value is the mean $\pm \mathrm{SEM}$.

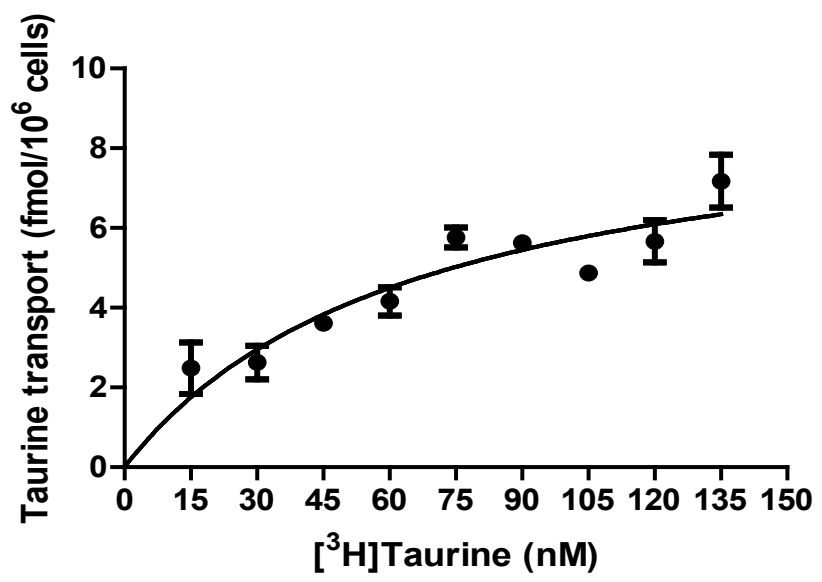

Figure 4: Curve of saturation of $\left[{ }^{3} \mathrm{H}\right]$ taurine transport. Was performed in the presence of different concentrations of $\left[{ }^{3} \mathrm{H}\right]$ taurine of 15 to $135 \mathrm{nM}$, with a time of preincubation of $5 \mathrm{~min}$ and $25 \mathrm{~s}$ of incubation at $37^{\circ} \mathrm{C}$. Fit hyperbola 1 site. $R^{2}=0.92, \mathrm{n}=4 . \mathrm{V}_{\max }=9.77 \pm 1.46 \mathrm{fmol} / 10^{6}$ cells and $\mathrm{K}_{\mathrm{t}}=0.08 \pm 0.04 \mu \mathrm{M} . \mathrm{K}_{\mathrm{t}}$ and $V_{\max }$ were determined by the method of double reciprocal of LineweaverBurk. Each value is the mean \pm SEM, $n=4$

These compartemental differences points to fine regulation of zinc levels due to proper activity of their transporters. The amount of zinc in some of the tissues of the eye is very high and in some animals could be twice the concentrations reported in other tissues [16]. Moreover, these authors indicate that the amount of zinc varies with age and type of ocular tissue, with highest concentration in the retina. In the human retina, zinc concentration is $100 \mu \mathrm{g} / \mathrm{g}[16,39]$, also present in cornea, vitreous humor, lens, iris and ciliary body [39]. The concentration of cellular zinc requires establishment of discrete, active cellular gradients. The cellular distribution of zinc into organelles is precisely managed to provide the zinc concentration required by each cell compartment. The complexity of zinc homeostasis is reflected by the surprisingly large variety and number of zinc homeostatic proteins found in virtually every cell compartment. In mammalian tissues, cytoplasmic $\mathrm{Zn}^{2+}$ concentration is maintained within a narrow range in the cells. Cells homeostatically adjust to $\mathrm{Zn}^{2+}$ excess by sequestering the metal ion in cytoplasmic vesicles or by increasing its efflux, and under conditions of zinc deficiency, $\mathrm{Zn}^{2+}$ influx is increased. These adjustments to zinc distribution and homeostasis involve complex cellular mechanisms that rely on many integral membrane transporters and metallochaperones to maintain a strict balance of intracellular zinc [40]. ZnT transporters are efflux transporters that reduce cytoplasmic $\mathrm{Zn}^{2+}$ concentrations by promoting zinc efflux from the cytoplasm to the extracellular compartment or into intracellular vesicles. ZIP transporters, on the other hand, are the influx transporters that mediate $\mathrm{Zn}^{2+}$ uptake into the cytoplasm from extracellular or vesicular sources [41].

Using various concentrations of the intracellular zinc chelator TPEN [9] and different periods of treatment, tested for selecting the dose to be used in further experiments (see Materials and Methods), we detected the reduction of zinc at specific conditions. The use of zinc chelators is an usuful alternative for restricting its levels in the cells. Moreover, the advantage of local injections allows exploring an area of interest and interpretation of the results could be less confusing. Intracellular zinc chelator, TPEN, among others, is one of the most widely used, for effectiveness and lack of toxicy at the administered dosis, in addition, it possesses high affinity for zinc $\left(4 \times 10^{-15} \mathrm{M}\right)[42$ $44]$. On the other hand, it has been reported that zinc deficient diets have little effect on the reduction of zinc in tissues such as the brain, for instance, decrease of $30 \%$ occurs after of 3 months in the hippocampus [43]. Thus, the determination of total zinc by ICP showed that this chelator produced a significant decrease of zinc in rat retina, and that had greater effect on the reduction of zinc at $\mathrm{nM}$ concentrations compared to the extracellular zinc chelator diethylenetriaminepentaacetic acid (DTPA) [25]. Intracellular chelators, such as TPEN, are usually more effective in reducing the metal and lower concentrations are required to cause the effect, as it has been previously shown in ex vivo studies of taurine transport [21] and with the in vivo results of this study. Depending on the amount of both, zinc released and chelator present, exogenous chelators might have either a neuroprotective or neurotoxic effect based on their ability to lower endogenous zinc levels $[43,45]$. The difference between the compartamental action, intra- or extracellular, for membrane-permeant and impermeant chelators, respectively, containing different zinc-binding ligands [38]. These facts might contribute to the observed differences. After studying several days of treatment with variable doses of TPEN, $5 \mathrm{nM}$ reduced the concentration of zinc in the rat retina 5 days after injection. It was observed that the reduction of the levels of zinc in the retina was time dependent and the concentration of the chelator. Since the at 3 and 10 days TPEN did not produce a significant decrease in zinc levels in the retinas of the eyes treated with different concentrations of the chelators compared to DMSO. Unlike, at 5 days after the io administration of TPEN in a concentration of $5 \mathrm{nM}$, zinc levels were significantly decreased as shown in Figure 1B. This treatment produced significant differences in various parameters of taurine as shown. These results suggest that zinc in the retina is associated with other molecules such as taurine, moreover, might be related to the formation of taurine-zinc complexes in cell membranes of retina. 


\section{Levels of taurine, taurine transport, mRNA of taurine transporter and effect of intracellular zinc chelator in retina}

The presence of zinc in the retina and its interaction with taurine contribute to the functional integrity of this structure $[16,39]$. Sturman et al. [46] demonstrated that taurine and zinc are located on the periphery of the rods in the retina of cat, and that reducing the concentration of taurine decreases zinc levels in rods, since both molecules form complexes that are inserted into to cell membrane for stabilization. Moreover, it has been shown that there is an increased in rat urine excretion of taurine due to zinc deficient diet [47]. Taurine and zinc protect photoreceptors from perooxidation in the retina of frog exposed to ferrous sulfate, and addition of taurine or zinc alone has no effect, although the conjoint supply of both molecules is protective [48]. Gottschal-Pass et al. [49] reported that taurine and zinc interact during development of the retina, they used light microscopy techniques and oscillatory potentials. These authors note that in rats fed zinc and taurine deficient diets occurs dysplasia in the retina, with photoreceptor degeneration and alterations in the oscillatory potentials.

There is no evidence about the effects of zinc on retinal taurine system of mammals, in regard to concentration, transport activity and relative levels of mRNA of transporter. It is known that zinc regulates several $\mathrm{Na}^{+} / \mathrm{Cl}^{-}$-dependent neurotransmitter transporters, such as that of dopamine [18,50], norepinephrine [19], serotonin [20], and taurine $[8,9,12,21]$. Dopamine, serotonin and taurine transporter belongs to the family of $\mathrm{Na}^{+} / \mathrm{Cl}^{-}$dependent transporters.

Taurine transport in isolated cells of the retina of goldfish and rat is mediated by two saturable components, of high and low affinity $[1,2]$, as we observed in the present study.

Since low levels of zinc, caused by TPEN treatment in vivo, produced significant decrease in taurine levels and transport, zinc might bind some site of TAUT that affect union or translocation of taurine, or possibly the formation of taurine-zinc complexes could be involved in maintaining the functional stability of the retina. It has been reported that zinc is a noncompetitive inhibitor of dopamine transporter and these effects occur due to binding to a particular transporter site affecting translocation of dopamine [51]. It has been shown that zinc increases serotonin uptake concentration-dependent manner in sections of the corpus callosum in adult rats [20]. It is not known if TAUT has residues of His in any of their domains, which may be the recognition site of the

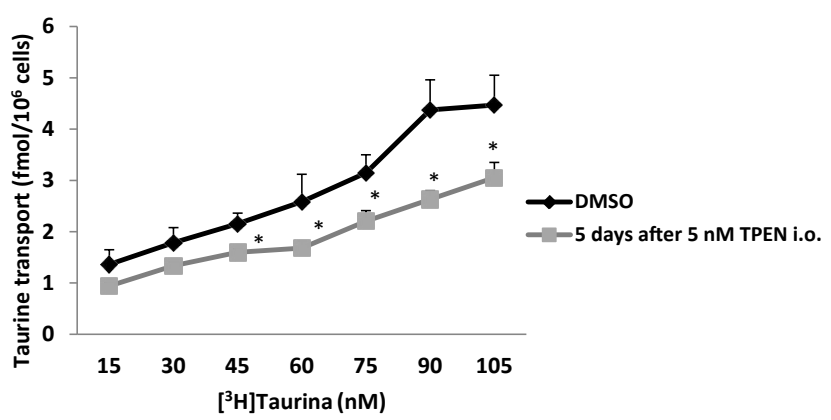

Figure 5: Effect of N,N,N,N-tetrakis-(2-pyridylmethyl) ethylenediamine (TPEN) in vivo on the of $\left[{ }^{3} \mathrm{H}\right]$ taurine transport. Cells $(200,00)$ were preincubated $5 \mathrm{~min}$ in Locke buffer at $37^{\circ} \mathrm{C}$. The transport was determined at different concentrations of $\left[{ }^{3} \mathrm{H}\right]$ taurine of $15-105 \mathrm{nM}$ and incubation time of $25 \mathrm{~s}$. The animals were treated with $5 \mathrm{nM}$ of TPEN and the transport was determined 5 days after the administration io. Each value is the mean \pm SEM, $n=4$. ${ }^{*} p<0.05$ with respect to DMSO group.

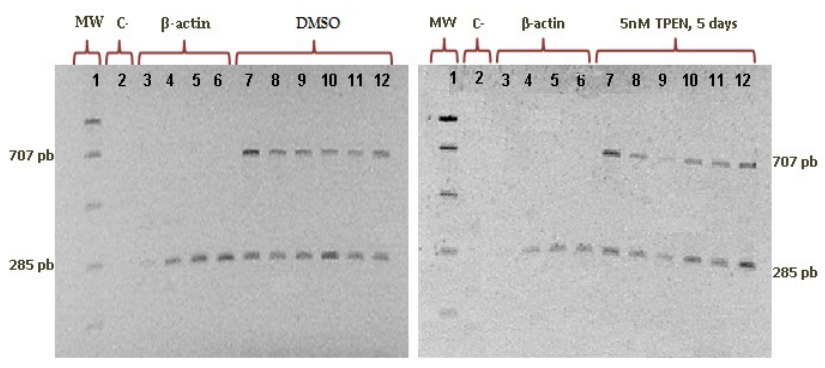

Figure 6: Agarose gel (2\%) of samples of DNA in control (DMSO) and TPEN treated rats expresing TAUT in retina and $\beta$-actin as constitutive standard for semi-quantities of mRNA for the transporter. Six representative samples in two gels, 1: Molecular Weight Markers (MW); 2: negative control; 3: $\beta$-actin $(0.025 \mu \mathrm{M}) ; 4$ : $\beta$-actin $(0.05 \mu \mathrm{M}) ; \beta$-actin $(0.1 \mu \mathrm{M} ; \beta$-actin $(0.5 \mu \mathrm{M})$. A. 7 to 12 : DMSO, TAUT (707 base pairs, bp)/ $\beta$-actin (285 bp). B. 7 to 12: 5 days after with $5 \mathrm{nM}$ TPEN treated, TAUT/ $\beta$-actin. $n=6$

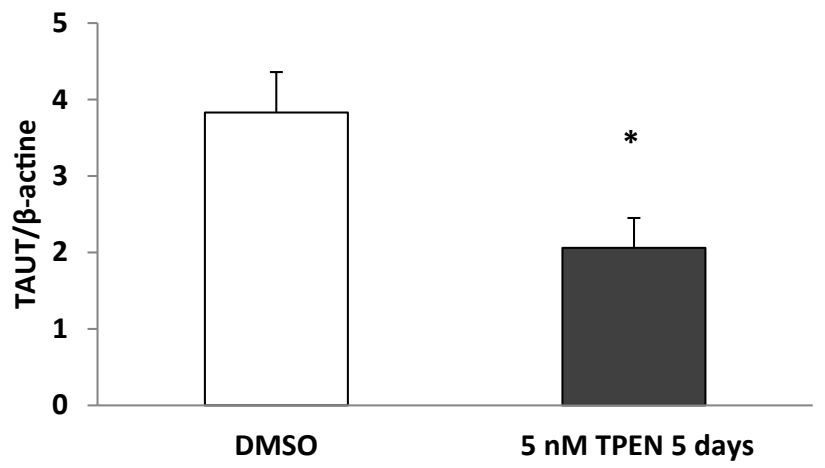

Figure 7: Densitometry analysis of the relative levels mRNA of TAUT. The results are expressed as the ratio of the intensities of the band corresponding to TAUT and the $\beta$-actin band. Each value is the mean \pm SEM, $n=6$. ${ }^{*} p 0.05$ with respect to DMSO.

metal, as demonstrated for serotonin [52] and dopamine transporters $[18,53]$. By mutagenesis and molecular models, binding sites of zinc to His and Cys residues has been identified in serotonin transporter, which are located near the extracellular ends of the transmembrane helices I and III [52]. The tertiary structure of dopamine transporter is modified, involving His193, His375 and Glu396 residues, which are close together [50]. Stockner et al. [53], by mutagenesis and structural changes, confirmed the presence of these residues interacting with zinc. Changes of transporter structure could influence its sensitivy to other regulatory processes, such as phosphorylation. Zinc has a direct inhibitory effect on glutamate transporter in cells of salamander retina [54]. In fact, it has been demonstrated that zinc has a biphasic effect on taurine transport ex vivo, stimulating it at low concentrations and inhibiting at high [21]. In the presence of 30 and $40 \mu \mathrm{M}$ there was a significant increase of the transport, concentrations of 100, 150 and $200 \mathrm{lM}$ of $\mathrm{ZnSO}_{4}$ reduced it. $\left[{ }^{3} \mathrm{H}\right]$ Taurine transport was significantly reduced with $20 \mu \mathrm{M}$ TPEN, incubating the cells with TPEN plus zinc, $100 \mu \mathrm{M}$, did not significantly affect it, and the presence of zinc in the incubation medium significantly decreased it. This evidence indicates that zinc affects various transport systems, including that of taurine in retina, as shown by our findings.

The genomic effects of zinc mediated by transcription factors could also be of relevance, including identified genes in intestine, thymus and monocytes involved in signal transduction, immune response, stress reactions, growth and energy utilization, which are regulated by proper 
Citation: Márquez A, Urbina M, Quintal M, Obregón F, Lima L (2016) Effects of Intracellular Zinc Chelator In Vivo on Taurine Transport, Taurine Concentrations and Taurine Transporter in Rat Retina Cells. J Membra Sci Technol 6: 149. doi:10.4172/2155-9589.1000149

Page 6 of 7

concentrations of zinc trough its transporters [55]. Significant changes in mRNA levels of TAUT in isolated rat retinal cells were observed 5 days after the io administration of TPEN, these results suggest that variations in taurine levels and transport could be due to changes in the relative levels of mRNA of TAUT. It has been suggested that one of the mechanisms regulating TAUT is by transcription factors, the promoter of TAUT has multiple binding sites for different transcription factors, which are: the tumor suppressor gene (P53), the transcriptional activator, $\mathrm{V}$-myb avian myeloblastosis viral oncogene homolog, activator protein-1, Wills' 1 tumor suppressor gene Wills' 1 (WT1), and protein specificity 1 (SP1) [3,56]. P53 requires zinc molecules to maintain its structure, sequence-specific binding to DNA depends on the metal $[57,58]$. WT1 and Sp1 are transcription factors which contain a zinc finger motif through which bind directly to DNA and promote transcription [59,60]. Recently, it has been suggested that Sp1 is necessary to activate the promoter of TAUT [56]. It could be that the decrease in zinc caused by TPEN modified transport activity, concentrations of taurine and levels of TAUT mRNA by effects on transcription factors regulated by zinc.

\section{Conflict of Interes}

There is no conflict of interest. The authors have non-financial competing interests in an exclusive academic way. A. Márquez is a PhD, who performed all experiments and writing. M. Quintal was in charge of zinc determinations. M. Urbina was participated in transport experiments and PCR assays. F. Obregón was in charge of taurine determinations. L. Lima, Chairperson and Tutor, provided with original idea, financial support, supervision of each experiments, analyzing results, discussion and writing

\section{Acknowledgments}

Instituto Venezolano de Investigaciones Científicas (IVIC-151), Venezuela. Asarí Márquez is a Post-Doctoral Fellow of Laboratory of Neurochemistry, Centro de Biofísica and Bioquímica, Instituto Venezolano de Investigaciones Científicas, Caracas, Venezuela.

\section{References}

1. Lima L (1999) Taurine and its trophic effects in the retina. Neurochem Res 24: $1333-1338$

2. Guerra A, Urbina M, Lima L (2000) Modulation of taurine uptake in the goldfish retina and axonal transport to the tectum. Effect of optic crush and axotomy. Amino Acids 19: 1-17.

3. Han X, Patters AB, Jones DP, Zelikovic I, Chesney RW (2006) The taurine transporter: mechanisms of regulation. Acta Physiol (Oxf) 187: 61-73.

4. Hillenkamp J, Hussain AA, Jackson TL, Constable PA, Cunningham JR, et al (2004) Compartmental analysis of taurine transport to the outer retina in the bovine eye. Invest Ophthalmol Vis Sci 45: 4099-4105.

5. Lima L, Matus P, Drujan B (1991) Differential taurine uptake in central and peripheral regions of goldfish retina. J Neurosci Res 28: 422-427.

6. Lima L, Cubillos S, Guerra A (2000) Regulation of high affinity taurine transport in goldfish and rat retinal cells. Adv Exp Med Biol 483: 431-440.

7. Militante $\mathrm{J}$, Lombardini $\mathrm{J}$ (1999) Stimulatory effect of taurine on calcium ion uptake in rod outer segments of the rat retina is independent of taurine uptake. J Pharmacol Exp Ther 291: 383-9.

8. Nusetti S, Urbina M, Lima L (2010) Effects of zinc ex vivo on taurine uptake in goldfish retinal cells. J Biomed Sci 17 Suppl 1: S13.

9. Nusetti S, Urbina M, Obregón F, Quintal M, Benzo Z, et al. (2010) Effects of zinc ex vivo and intracellular zinc chelator in vivo on taurine uptake in goldfish retina. Amino Acids 38: 1429-1437

10. Tappaz ML (2004) Taurine biosynthetic enzymes and taurine transporter: molecular identification and regulations. Neurochem Res 29: 83-96.

11. Nag TC, Jotwani G, Wadhwa S (1998) Immunohistochemical localization of taurine in the retina of developing and adult human and adult monkey. Neurochem Int 33: 195-200.
12. Nusetti S, Salazar V, Lima L (2009) Localization of taurine transporter, taurine and zinc in goldfish retina. Adv Exp Med Biol 643: 233-242.

13. Orr HT, Cohen Al, Lowry OH (1976) The distribution of taurine in the vertebrate retina. J Neurochem 26: 609-611.

14. Pow DV, Sullivan R, Reye P, Hermanussen S (2002) Localization of taurine transporters, taurine, and (3)H taurine accumulation in the rat retina, pituitary, and brain. Glia 37: 153-168.

15. Vallee BL, Falchuk KH (1993) The biochemical basis of zinc physiology. Physiol Rev 73: 79-118.

16. Ugarte M, Osborne NN (2001) Zinc in the retina. Prog Neurobiol 64: 219-249.

17. Vishwanathan R, Chung M, Johnson EJ (2013) A systematic review on zinc for the prevention and treatment of age-related macular degeneration. Invest Ophthalmol Vis Sci 54: 3985-3998.

18. Scholze P, Nørregaard L, Singer EA, Freissmuth M, Gether U, et al. (2002) The role of zinc ions in reverse transport mediated by monoamine transporters. J Biol Chem 277: 21505-21513.

19. Nørgaard-Nielsen K, Gether $U$ (2006) $\mathrm{Zn}^{2+}$ modulation of neurotransmitter transporters. Handb Exp Pharmacol pp: 1-22.

20. García-Colunga J, Reyes-Haro D, Godoy-García IU, Miledi R (2005) Zinc modulation of serotonin uptake in the adult rat corpus callosum. J Neurosci Res 80: 145-149.

21. Márquez A, Urbina $M$, Lima L (2014) Zinc and zinc chelators modify taurine transport in rat retinal cells. Neurochem Res 39: 2234-2239.

22. Márquez A, Salazar V, Lima L (2015) Localization of Taurine Transporter and Zinc Transporters in Rat Retinal Cells and Tissue. Effect of Intracelular Zinc Chelation. J Mol Pathophysiol 4: 42-50.

23. Jayo M, Cisneros F (1996) GuÃa para el Cuidado y Uso de los Animales de Laboratorio. Copyright National Academy Press, Washington, DC.

24. Smith PK, Krohn RI, Hermanson GT, Mallia AK, Gartner FH, et al. (1985) Measurement of protein using bicinchoninic acid. Anal Biochem 150: 76-85

25. Nusetti S, Obregón F, Quintal M, Benzo Z, Lima L (2005) Taurine and zinc modulate outgrowth from goldfish retinal explants. Neurochem Res 30: 14831492

26. Lima L, Obregon F, Matus $P$ (1998) Taurine, glutamate and GABA modulate the outgrowth from goldfish retinal explants and its concentrations are affected by the crush of the optic nerve. Amino Acids 15: 195-209.

27. Fleige S, Walf V, Huch S, Prgomet C, Sehm J, et al. (2006) Comparison of relative mRNA quantification models and the impact of RNA integrity in quantitative real-time RT-PCR. Biotechnol Lett 28: 1601-1613.

28. Yuan LQ, Xie H, Luo XH, Wu XP, Zhou HD, et al. (2006) Taurine transporter is expressed in osteoblasts. Amino Acids 31: 157-163.

29. Hansen DB, Friis MB, Hoffmann EK, Lambert IH (2012) Downregulation of the taurine transporter TauT during hypo-osmotic stress in NIH3T3 mouse fibroblasts. J Membr Biol 245: 77-87.

30. Nishimura T, Sai Y, Fujii J, Muta M, lizasa H, et al (2010) Roles of TauT and system $A$ in cytoprotection of rat syncytiotrophoblast cell line exposed to hypertonic stress. Placenta 31: 1003-1009.

31. Zhou C, Zhang X, Xu L, Wu T, Cui L, et al. (2014) Taurine promotes human mesenchymal stem cells to differentiate into osteoblast through the ERK pathway. Amino Acids 46:1673-80.

32. Liu S, Liu Y, Ma Q, Cui S, Liu J (2015) Expression and localization of cysteine sulfinate decarboxylase in major salivary glands of male mice. Arch Oral Bio 60: 615-621.

33. Smith KE, Borden LA, Wang CH, Hartig PR, Branchek TA, et al. (1992) Cloning and expression of a high affinity taurine transporter from rat brain. Mol Pharmacol 42: 563-569.

34. Urbina M, Arroyo R, Lima L (2014) 5-HT7 receptors and tryptophan hydroxylase in lymphocytes of rats: mitogen activation, physical restraint or treatment with reserpine. Neuroimmunomodulation 21: 240-249.

35. Tapia F (1994) GraphPad Instat Softward. V2.05a

36. Huang L, Kirschke CP, Gitschier J (2002) Functional characterization of a nove mammalian zinc transporter, ZnT6. J Biol Chem 277: 26389-26395. 
Citation: Márquez A, Urbina M, Quintal M, Obregón F, Lima L (2016) Effects of Intracellular Zinc Chelator In Vivo on Taurine Transport, Taurine Concentrations and Taurine Transporter in Rat Retina Cells. J Membra Sci Technol 6: 149. doi:10.4172/2155-9589.1000149

37. Zuo XL, Chen JM, Zhou X, Li XZ, Mei GY (2006) Levels of selenium, zinc, copper, and antioxidant enzyme activity in patients with leukemia. Biol Trace Elem Res 114: 41-53.

38. Frederickson CJ, Suh SW, Silva D, Frederickson CJ, Thompson RB (2000) Importance of zinc in the central nervous system: the zinc-containing neuron. J Nutr 130: 1471S-83S

39. Grahn BH, Paterson PG, Gottschall-Pass KT, Zhang Z (2001) Zinc and the eye. J Am Coll Nutr 20: 106-118.

40. Leung KW, Liu M, Xu X, Seiler MJ, Barnstable CJ, et al. (2008) Expression of $\mathrm{ZnT}$ and ZIP zinc transporters in the human RPE and their regulation by neurotrophic factors. Invest Ophthalmol Vis Sci 49:1221-31

41. Cousins RJ, Liuzzi JP, Lichten LA (2006) Mammalian zinc transport, trafficking, and signals. J Biol Chem 281: 24085-24089.

42. Lees G, Cuajungo M, Leong W (1998) Effect of metal chelanting agents on the direct and seizure-related neuronal death induced by zinc and kainic acid. Brain Res 799: 108-109.

43. Cuajungco MP, Lees GJ (1998) Diverse effects of metal chelating agents on the neuronal cytotoxicity of zinc in the hippocampus. Brain Res 799: 97-107.

44. Nakatani T, Tawaramoto M, Kojima K, Matsui-Yuasa I (2000) Apoptosis induced by chelation of intracellular zinc is associated with depletion of cellular reduced glutathione level in rat hepatocytes. Chem Biol Interact 125: 151-163.

45. Armstrong C, Leong W, Lees G (2001) Comparative effects of metal chelating agents on the neuronal cytotoxicity induced by copper $\left(\mathrm{Cu}^{2+}\right)$, iron $\left(\mathrm{Fe}^{3+}\right)$ and zinc in the hippocampus. Brain Res 892: 51-62.

46. Sturman JA, Wen G, Wisniewski H, Hayes K (1981) Histochemical localization of zinc in the feline tapetum: Effect of taurine depletion. Histochemistry 72 : 341-350.

47. Wallwork JC, Sandstead HH (1983) Effect of zinc deficiency on appetite and free amino acid concentrations in rat brain. J Nutr 113: 47-54.

48. Pasantes-Morales $\mathrm{H}$, Cruz C (1984) Protective effect of taurine and zinc on peroxidation-induced damage in photoreceptor outer segments. J Neurosci Res 11: 303-311.
49. Gottschall-Pass K, Grahn B, Gorecki D, Paterson P (1997) Oscillatory potentials and light microscopic changes demonstrate an interaction between zinc and taurine in the developing rat retina. J Nutr 127: 1206-1213.

50. Norgaard-Nielsen K, Norregaard L, Hastrup H, Javitch J, Gether U (2002) Zn2+ site engineering at the oligomeric interface of the dopamine transporter. FEBS Lett 524: 87-91.

51. Norregaard L, Frederiksen D, Nielsen EO, Gether U (1998) Delineation of an endogenous zinc-binding site in the human dopamine transporter. EMBO 17: $4266-4273$.

52. White K, Kiser P, Nichols D, Barker E (2006) Engineered zinc-binding sites confirm proximity and orientation of transmembrane helices I and III in the human serotonin transporter. Protein Sci 15: 2411-2422.

53. Stockner T, Montgomery T, Kudlacek O, Weissensteiner R, Ecker G, et al (2013) Mutational analysis of the high-affinity zinc binding site validates a refined human dopamine transporter homology model. PLoS Comput. Biol 9: 1002909.

54. Spiridon M, Kamm D, Billups B, Mobbs P, Attwell D (1998) Modulation by zinc of the glutamate transporters in glial cells and cones isolated from the tiger salamander retina. J Physiol 506: 363-376.

55. Cousins RJ, Blanchard RK, Moore JB, Cui L, Green CL, et al. (2003) Regulation of zinc metabolism and genomic outcomes. J Nutr 133: 1521-6.

56. Chesney R, Patters A, Han X (2012) Taurine in the kidneys El Idrissi A, L $\hat{A}^{\prime}$ Amoreaoux W (eds) Taurine in health and disease, Transworld Research Network, Kerala, India pp: 7599.

57. Butler JS, Loh SN (2003) Structure, function, and aggregation of the zinc-free form of the p53 DNA binding domain. Biochemistry 42: 2396-2403.

58. Hainaut $P$, Mann K (2001) Zinc binding and redox control of p53 structure and function. Antioxid Redox Signal 3: 611-623.

59. Ito T, Azumano M, Uwatoko C, Itoh K, Kuwahara J (2009) Role of zinc finger structure in nuclear localization of transcription factor Sp1. Biochem Biophys Res Commun 380: 28-32.

60. Laity JH, Lee BM, Wright PE (2001) Zinc finger proteins: new insights into structural and functional diversity. Curr Opin Struct Biol 11: 39-46. 